Journal of Business School
$2019,2(4): 31-44$
DOI: $10.26677 / \mathrm{TR} 1010.2019 .105$
Journal Homepage: https://www.journalbusiness.org

\title{
The Growth Factor of Money Supply on Economic Growth And Inflation in Nigeria
}

\author{
Ikpaikpai Helen Idisebara \\ Department of Banking \& Finance, Niger Delta University, Wilberforce Island, Bayelsa \\ State, Nigeria. idisebara4real@gmail.com
}

\begin{abstract}
The study investigated the impact of money supply on macroeconomic variables in Nigeria from 1985 to 2016. The specific objectives of the paper were to ascertain the impact of narrow money supply, broad money supply, inflation rate, and exchange rate on real gross domestic product on one hand, and narrow money supply, broad money supply and exchange rate on consumer price index in Nigeria. The ex post facto research design and descriptive statistics were used to observe the variables in retrospect. To achieve the objectives of the study, two models were built to mimic the tread. To avoid spurious results, the Augmented Dickey Fuller test was used to solidify the data, which integrated at first difference I(1). The ordinary least square technique was employed to determine the magnitude and direction of the variables in the models. It emerged that narrow money supply has a positive and significant impact on inflation and real gross domestic product; conversely, broad money supply does not have any significant impact on inflation and real gross domestic product. Empirical evidence further showed that exchange rate has an insignificant impact on inflation and real gross domestic product. Inflation rate on the other hand, has an inverse and statistically insignificant impact on real gross domestic product in Nigeria. The results suggest that economic growth and inflation is a function of money supply (narrow money supply) and exchange rate in Nigeria. The paper recommends that efforts should be put in place to better the exchange rate between the naira and other currencies. This will help avoid the imported inflationary pressure on goods and services in the country.
\end{abstract}

Keyword: Economic growth, real gross domestic product, narrow money supply, broad money, exchange rate, inflation

\section{Introduction}

It is on record that economic revolution started in England in the late $18^{\text {th }}$ century and gradually spread to other part of Europe and North America. Specifically, economic transformation did not get to other part of the world until in the 1950s when Japan became transformed. This economic growth has spread far and wide in recent times but its spread is highly limited in Africa. This was demonstrated by the World Bank report (2001), which states that out of the 46 poorest countries in the world 35 of them are in Africa.

Nigeria presents a clear liken to a third world economy in which the economy is predominately reliant on crude oil for its economic survival. Nigeria's economic aspirations have remained 
that of altering the structure of production and consumption patterns, diversifying the economic base and reducing dependence on oil, with the aim of putting the economy on a part of sustainable, all-inclusive and non-inflationary growth. The implication of this is that while rapid growth in output, as measured by the real gross domestic product (GDP), is important, the transformation of the various sectors of the economy is even more critical. This is consistent with the growth aspirations of most developing countries, as the structure of the economy is expected to change as growth progresses.

The Nigerian economy has been plagued with several challenges over the years. In spite of many, and frequently changing policies, Nigeria has not been able to harness her economic potentials for rapid economic growth and development (Ogbole, 2010). Today, monetary and fiscal policies are both commonly accorded prominent roles in the pursuit of macroeconomic stabilization in developing countries, but the relative importance of these policies has been a serious debate between the Keynesians and the monetarists. The monetarists believe that monetary policy exert greater impact on economic activity while the Keynesian believe that fiscal policy rather than the monetary policy exert greater influence on economic activity. Despite their demonstrated efficacy in other economies as policies that exert influence on economic activities, both policies have not been sufficiently or adequately used in Nigeria (Ajisafe \& Folorunsho, 2002).

Over the years, the question of the existence and nature of the link between money supply and inflation has been a subject of considerable interest and debate. The major problem that triggered off this work is the occurrence of the general feeling that a continuous annual rate of money increase will adversely increase the rate of price level which will directly lead to inflation. Thus inflationary pressures in the country over the years have succeeded in bringing about devaluation of the naira as a result of expansionary measures. Money is more closely related to aggregate level of spending, prices, income production and employment than any other single economic variable. An excess in supply of money results in excess demand of goods and services and in turn lead to price increase and or deterioration of the balance of payment position. Typically, in periods of high inflation, the horizon of the investor is short, and resources are diverted from long term investment to those with immediate returns and inflation hedges, including real estate and currency speculation. .

Nigeria has experienced general price increase since the 1970s. The adoption of the Structural Adjustment Programmes in 1986 resulted in increase in inflation rates as well as in exchange rates. The privatization and deregulation policies were among other things aimed at controlling inflation, yet inflation continued to rise.

The upsurge and incessant increase in the prices of goods and services in Nigeria in recent times is worrisome. The heat from the global economic meltdown is yet to cool off; inflationary gap and inflationary spiral are witnessed in our economy (Anyanwu \& Kalu, 2015). People are demanded to pay more than they used to pay to purchase goods and services. The rate of inflation in Nigeria today is fast and difficult to predict, the wind of price changes is blowing like never before. Coupled with this is the poor economic growth recorded in the past three decades in comparison with population growth. This could be as a result of failure of monetary policy to maintain price stability.

Considerable scholarly effort have been concentrated on the impact of money supply on economic growth in Nigeria, but the result has been inconsistent and controversial, some recorded positive growth on GDP while other recorded negative impact. The inflation volatility in the process is a major concern. This has created the avenue for further studies to contribute to knowledge building. 


\section{Objectives of the Paper}

The broad objective of this paper is to scrutinize the impact of money supply on inflation and economic growth in Nigeria. The specific objectives of this paper are;

(1) To investigate the impact of narrow money supply on inflation and real gross domestic product in Nigeria.

(2) To determine the impact of broad money supply on inflation and real gross domestic product in Nigeria.

(3) To determine the impact of exchange rate on inflation and real gross domestic product in Nigeria.

(4) To ascertain the impact of inflation on real gross domestic product in Nigeria.

\section{Empirical Literature Review}

Several studies have been carried out to ascertain the impact of money supply on economic growth and inflation in developing and developed countries with varying results and conclusions. For instance, Mamo (2012) in a cross country study employed fixed effect panel model and Panel Granger causality to test the effect and causal relationship between inflation and economic growth. The study used strongly balanced panel data which contained 13 SSA countries covering 1969-2009. The estimation results showed that inflation was negatively and significantly related to economic growth. It means that inflation has an adverse effect on economic growth. The Panel Granger causality test showed that inflation Granger causes economic growth for all countries in the sample, while economic growth Granger causes inflation for two countries. Similarly, Chaturvedi, Kumar, \& Dholakia (2009) equally used a simultaneous equation model for a panel of 140 countries over the 1970-2005 periods to show that there exists a bilateral causal relationship between the growth and inflation as predicted by recent theories. Most importantly, the results indicated that inflation is harmful to growth whereas the effect from growth to inflation is beneficial. Doroshenko (2001) also considered the relationship between money supply and inflation. The findings confirmed a long-run relationship between money growth and inflation.

A recurring debate in the country specific literature on the effectiveness of monetary policy to stabilize the Nigerian economy in terms of price stability and subsequently stimulating economic growth and stability of money demand function that need not to be ignored in a study of this nature about Nigeria is the "TATTOO DEBATE" put forward by Tomori (1972) which found income, interest rate and real income to be the major determinants of demand for money in Nigeria. Owing to perceived shortcomings of Tomori's work, Ajayi (1974), Teriba (1974), Ojo (1974) and Odama (1974) questioned that postulation and came up with their own positions. Consequently the debate centred around the significance of income in money demand function for Nigeria, the stability of the function, and the choice of appropriate definition of money in Nigeria.

On the issue of income, in line with Tomori (1972) assertion, Teriba (1974) and almost all the other scholars agreed that income is the most significant determinant of money demand in Nigeria. On interest rate, Teriba (1974) contrasted Tomori (1972) view by arguing that long term interest rate is significant (unstable demand for money) but short term rates are insignificant (stable demand for money function). Those who however, argued that the rate of interest is not significant have two reasons for their argument (Mai-Lafia, 1995). Firstly, the interest rates have remained relatively stable in developing countries so that there is too little variation to allow conventional estimators to capture the effect of interest rates in the demand for money function. Secondly, that owing to the underdeveloped nature of the financial structure of less developed countries, the substitution between money and real assets may be quantitatively more 
important than that between money and financial assets. Owoye \& Onafowora (2007) found income elasticity of 2.067 for Nigeria and interest elasticity of 0.306 . On the appropriate definition of money demand in Nigeria, Tomori concludes that $\mathrm{M}_{1}$ performs better than $\mathrm{M}_{2}$. In contrast, Ajayi (1974) asserts that $\mathrm{M}_{2}$ performs better than $\mathrm{M}_{1}$. In an attempt to mediate between Tomori (1972) \& Ajayi (1974), Gwosh (1981) contends that both $\mathrm{M}_{1}$ and $\mathrm{M}_{2}$ can be used as the definition of money in Nigeria. As lively as the debate was, the issue still remains inconclusive. Several studies have been conducted around the globe on the subject matter.

Following this debate, Nwaobi (2002) made efforts to examine the stability of the Nigeria's money demand function and found it to be stable. Nwaobi (2002) then suggests that monetary policy could be effective and that income is an appropriate determinant in the estimation of money demand in Nigeria. Anoruo (2002) explores the stability of $\mathrm{M}_{2}$ money demand function in Nigeria during the Structural Adjustment Programme (SAP) period. He observed that $\mathrm{M}_{2}$ money demand function in Nigeria is stable for the study period. Again, like Nwaobi (2002), he asserts - using $\mathrm{M}_{2}$ money demand function, that it is a viable monetary policy tool that could be used to stimulate economic activity in Nigeria.

Recently, Gatawa, Akinola, Muftau, \& Olarinde (2017) empirically examined the impact of money supply, inflation, and interest rate on economic growth in Nigeria using time series data from 1973-2013. VAR model and Granger Causality test within error correction framework were used. The results of the VEC model provided evidence in support of a positive impact of broad money supply while inflation and interest rate exhibits a negative impact on growth most especially in the long run. The short run parsimonious results revealed that with the exception of inflation, broad money supply and interest rate were negatively related to economic growth. For the test of causality, it was revealed that none of the explanatory variables granger causes economic growth, implying that money supply, inflation and interest rate have not influenced growth.

Chinuba, Akhor, \& Akwaden (2015) used time series data to study the impact of money supply on economic growth covering 1981-2008 with simple OLS on the Nigeria economy, the results showed that money supply exerted a considerable positive impact on economic growth. An investigation into the long-run and short-run impact of money supply on economic growth of Nigeria for the period 1986-2006 was carried out by Omotor, (2010) using VAR Model, the results provide evidence in support of the long run positive impact of money supply on growth in income but has no impact in the short-run.

Similarly, Aziakpono (2003) presented and tested a model on money supply and economic growth to determine either or both anticipated and unanticipated money affects real output and growth in Nigeria. The evidence revealed that while anticipated money supply affects real output and growth in Nigeria, the unanticipated money supply did not. Omoke \& Ugwuanyi (2010) tested the relationship between money, inflation and output by employing co-integration and Granger-causality test analysis. The findings revealed no existence of a co-integrating vector in the series used. Money supply was seen to Granger cause both output and inflation. The result suggest that monetary stability can contribute towards price stability in Nigerian economy since the variation in price level is mainly caused by money supply and also conclude that inflation in Nigeria is to a large extent a monetary phenomenon. $\mathrm{M}_{2}$ appeared to have a strong causal effect on the real output as well as prices.

Abbas \& Husian (2006) examines the casual relationship between money and income and money and prices in Pakistan. The co-integration analysis indicates, in general, the long run relationship among money, income and prices. The error correction and Granger causality framework suggest a one-way causation from income to money in the long run implying that probably real factors rather than money supply have played a major role in increasing 
Pakistan's national income, regarding the causal relationship between money and prices, the causality frame work provides the evidence of bi-variate causality indicating that monetary expansion increases and is also increased by inflation in Pakistan. However, money supply seems to be the leader in this case.

Akujuobi (2010) studied monetary policy and Nigeria's economic development using multiple regression analysis, namely; gross domestic product (dependent variable) and independent variables: Cash Reserve Ratio (CRR), Liquidity Ratio (LQR), interest rate, Minimum Rediscount Rate (MRR) and the treasury bill rate and found out that apart from cash reserve ratio, others impacted much on the economic development of the nation.

Similarly, Chimobi \& Uche (2010) examined the relationship between money, inflation and output in Nigeria. The study adopted co-integration and granger causality test analysis. The cointegrating result of the study showed that the variables used in the model exhibited no long run relationship among each other. Nevertheless, money supply was seen to granger cause both output and inflation. The result of the study suggested that monetary stability can contribute towards price stability in the Nigerian economy since the variation in price level is mainly caused by money supply and concluded that inflation in Nigeria is to an extent a monetary phenomenon.

Usman \& Adejare (2014) empirically examined the effect of money supply, foreign exchange on Nigeria economy with secondary data covering the period of 1988 to 2010. Multiple regressions were employed to analyze the variables; gross domestic product (GDP), Narrow Money, Broad money, exchange rate and interest rate. The results found that all the variables have significant effects on the economic growth with the adjusted $\mathrm{R}^{2}$ showing that about $97.3 \%$ variation in the GDP from 1988 to 2010 is due to NARM.

Similarly, Aminu \& Amono, (2012) conducted an empirical investigation into the effect of inflation on the growth and development of Nigeria economy. The work employed Cobb Douglas Production function with ordinary least square method and concluded that inflation possess a positive impact on economic growth. Osuala, Osuala, \& Onyeike (2013) carried out an empirical study on the impact of inflation on economic growth over a period of thirty-one years. The VAR results revealed a statistically significant positive impact of inflation on economic growth in Nigeria while the causality test showed that there is no causality in between the two variables. In the same vein, Taiwo (2011) investigated the impact of inflation and investment on economic growth in Nigeria with the use of ordinary least square (OLS) method and annual secondary data from 1981 to 2006, the investigation based on inflation-GDP revealed that inflation has negative and insignificant impact on economic growth, meaning that as inflation increases economic growth falls.

Ifionu \& Akinpelumi (2015) examined the effect and implication of selected macroeconomic variables on money supply $\left(\mathrm{M}_{2}\right)$, using derived secondary data gotten from the Central Bank Statistical Bulletin (2013). Coupled with the application of econometric technique such as; O.L.S., causality test and Co-integration of time series data to estimate the long and short run relationship and causality of employed variables. The results revealed that all variables were stationary at various lags and there exists a long run relationship between variables employed and it was discovered that apart from inflation had an inverse significance with money supply $\left(\mathrm{M}_{2}\right)$ and exchange Rate (EXR), all other variables such as gross domestic Product (GDP) were found to have a positive impact on money supply.

Malik (2006) studied the effects of monetary policy actions on inflation using Near-VAR approach. His results showed that effect of monetary policy transmits into inflation with a lag of half year and then take another year to reach the peak. This study suggested the 
identification of variables that are most important in explaining inflation in Pakistan by considering monetary policy actions, supply side factors and foreign inflation.

Kenneth, Yuni, \& Ihugba (2016) investigated the relationship between inflation and economic growth in Nigeria using a two stage least square estimation to examine the simultaneous models of the study. The study showed that inflation is beneficial to growth though not significantly while growth is significantly beneficial to inflation; given the positive relationship between inflation and growth and the negative relationship between growth and inflation. The results further showed that money supply and trade openness are significant determinants of real GDP for all three estimation techniques under consideration. While, real GDP, money supply and interest rate are significant determinants of inflation.

Furthermore, Femi (2014) the study examined the effect of economic variables such as inflation, income; interest rates, price level and exchange rate have on demand for money, by applying regression analysis with an Error Correction Model (ECM) on various economic variables, covering a period of thirty-three years (1970-2003). The study revealed that inflation was not affected by trend but by Nigerian government policies and that inflation does not exert any significant influence on demand for money.

Adeyeye \& Fakiyesi (1980) estimated and tested the hypothesis that the main factor responsible for instability of prices and inflationary tendencies in Nigeria was government expenditure. Working with annual time series data spanning 1960-1977, they tested the hypothesis that the rate of inflation in Nigeria is linearly related to the rate of growth of money stock, government expenditure, especially deficit, and growth of government revenue, especially monetization of foreign exchange from oil export. The result established some significant positive relationships between inflation rate and growth in bank credit, growth of money supply and growth in government expenditure, while the relationship with growth of government revenue was uncertain.

Baghelo \& Ebibai (2014) empirically examined the impact of monetary policy on selected macroeconomics variables such as gross domestic product, inflation, and balance of payment in Nigeria from (1980-2011) using ordinary least square (OLS) regression analysis. The error correction method is used to ascertain if there is a static long run equilibrium relationship among the explanatory variables and subsequently derive an adequate dynamic model of the short run relationship. The study showed that the provision of investment friendly environment in the Nigerian economy will increase the growth rate of GDP.

Nwaobi (2002) used data from 1960 through 1995 and the Johansen co-integration framework found that money demand, real GDP, inflation and interest rate are co integrated in Nigeria. He also found stable money demand in the period under study. Fatukasi (2004) investigated the determinants of inflation in Nigeria between 1981 and 2003. The study made use of non-linear multiple regression models. He posited that the causes of inflation in Nigeria are multidimensional and dynamic, requiring full knowledge at any point in time to be able to proffer solutions to the inflationary trends in the country. Also, Omoke (2010) tested the causal longterm relationship between budget deficit, money growth and inflation in Nigeria. Augmented Dickey-Fuller (ADF) and Philip-Perron (PP) test were carried out to test the stationarity of the variables used. The result of the study pointed to a close long-term relationship between inflation and money supply.

In another country specific study, Olusanya (2009) analyzed the main sources of fluctuations in inflation in Nigeria. Using the framework of error correction mechanism (ECM) it was found that the lagged CPI, expected inflation, petroleum prices and real exchange rate significantly propagate the dynamics of inflationary process in Nigeria. Bakare (2011) conducted a study on the determinants of money supply growth and its implications on inflation in Nigeria. The 
study employed quasi-experimental research design approach. The results showed that credit expansion to the private sector determines money supply growth and inflation in Nigeria. He therefore concluded that changes in money supply are concomitant to inflation in Nigeria.

Anyanwu \& Kalu (2015) examined the correlation that exists between money supply and economic growth using time series data for 18 years (1994-2012) on money supply, CLBA and output. The findings showed that change in money supply (M2) has significant effect on variables such as CBLA and output in Nigerian economy within the period under review. It also showed that there is a significant strong multiple correlation among Real GDP, money supply and commercial banks' loans and advances $(R=95.1 \%)$. The coefficient of Determination $\left(R^{2}\right)$ reveals that $90.5 \%$ of variations in RGDP were explained by the selected explanatory variables.

Abdulazeez (2016) using time-series data covering 1990 to 2010, investigated the impact of monetary policy on economic growth in Nigeria. With the aid of multiple regressions analysis technique on money supply, interest rate, and financial deepening on gross domestic product, the study found that all the variables have marginal impact on the economic growth of Nigeria.

\section{Significance of the Paper}

Judging by the foregoing, it can be seen that so many studies have been carried out about the impact of money supply on macroeconomic variables in Nigeria. We note from the review that several scholars used broad money supply as one of the measure for money supply while neglecting narrow money supply. This study added narrow money supply plus a combination of broad money, inflation rate, and exchange rate to ascertain their impact on real gross domestic product in Nigeria; this is aimed at contributing to knowledge building. The researcher also used current time series data on narrow and broad money supply, and exchange rate to ascertain the impact of these variables on the general price level in Nigeria; this is aimed at building on the current empirical knowledge base of this topic in Nigeria.

\section{Research Design}

The Ex-Post Facto research design was adopted to examine the impact of money supply on some macroeconomic variables in Nigeria. This design was adopted to enable the researcher to use time series data to explain the impact of narrow and broad money supply, inflation rate, and exchange rate on real gross domestic product on one hand, and narrow and broad money supply and exchange rate on consumer price index in Nigeria in retrospect.

In addition to this design, the author used descriptive statistics and empirical analytical methods like Augmented Dickey-Fuller (ADF) test to solidify the data, Johansen co-integration test to determine the long run relationship in the variables, and multiple regressions to determine the impact of the variables on the explanatory variables in the study.

\section{Model Specification}

The study imitated finance literature and adopted the Multiple Regression using the Ordinary Least Squares like Usman \& Adejare (2014), Baghelo \& Ebibai (2014), Ifionu \& Akinpelumi (2015) to examine the impact of narrow and broad money supply, inflation rate, and exchange rate on real gross domestic product on one hand, and narrow and broad money supply and exchange rate on consumer price index in Nigeria in retrospect in the other hand. The Ordinary Least Squares (OLS) technique is used because it is the most unbiased estimator, consistency, minimum variance and efficiency.

Consequently, the study assumed that real gross domestic product is a function of narrow and broad money supply, inflation rate, and exchange rate, and that consumer price index is a function of narrow and broad money supply and exchange rate in Nigeria. Thus, the 
mathematical and econometric model follows the augmented technique used by McCallum (1991) and Kohn (1999).

The functional models are stated as follows;

$R G D P=f\left(M 1, M_{2}, I N F R, E X R\right)$

$I N F R=f\left(M 1, M_{2}, I N F R, E X R\right)$

This is expressed econometrically as follows;

$R G D P G R=\beta_{0}+\beta_{1} M_{1}+\beta_{2} M_{2}+\beta_{3} I N F R+\beta_{3} E X R+u \quad$ III

$I N F R=\beta_{0}+\beta_{1} M_{1}+\beta_{2} M_{2}+\beta_{3} E X R+u$

Where;

RGDP $=$ Growth rate of real Gross Domestic Product

INFR = Inflation rate

$\mathrm{M}_{1}=$ Narrow money supply

$\mathrm{M}_{2}=$ Broad money supply

$\mathrm{EXR}=$ Exchange Rate

$\mathrm{u}=$ Stochastic term

$\beta_{1 \text { to }} \beta_{4}=$ Parameter estimates

A priori Expectations

$\beta_{1}>0, \beta_{2}>0, \beta_{3}>0, \beta_{4}>0$.

The implication of this is that all the coefficients of the explanatory variables are expected to have a linear impact on the dependent variables.

\section{Operational Description of the Variables}

1. Narrow Money Supply (M)- Currency outside bank plus demand deposits of commercial banks.

2. Broad Money Supply $\left(\mathbf{M}_{2}\right)$ - M1 plus quasi money. Quasi-money is defined as the sum of savings and time deposits with commercial banks.

3. Inflation - general increase in prices of goods and services over a period of time in Nigeria.

4. Gross Domestic Product - the total market value of all final goods and services produced in Nigeria annually.

5. Exchange Rate - the value of the naira against other currencies.

\section{Methods of Data Analysis}

The Augmented Dickey-Fuller (ADF) test was employed to solidify the data to avoid spurious results that are misleading. The researcher further employed the Ordinary Least Squares (OLS) technique to estimate and evaluation of the models of the study.

The evaluation consists of deciding whether the parameters are meaningful and statistically satisfactory (Iyoha, 2004). The coefficients of the parameters were validated on theoretical a priori criteria - that is, the signs and size of the magnitude of the estimated parameters are judged based on what economic theory postulates. Note in some cases, the signs and magnitudes may not always reflect a priori expectation.

Furthermore, we used the statistical criteria to read meaning to the OLS outputs. The statistical measures are the correlation coefficient of the adjusted $\left(R^{2}\right)$, standard error (SR), and standard deviation of the estimates, $\mathrm{t}$-statistics and f-statistics. It should be noted that the $\mathrm{R}^{2}$ gave us the 
insight or measure of the extent of degree to which the explanatory variables are explained the changes in the dependent variables.

The standard deviation, as the name implies measures the rate of dispersion of the estimates around the true parameters because the higher the standard deviation (standard error) of the parameter, the less reliable it is, and vice versa.

The $t$-test is an offshoot of the standard error test. The $t$-test estimates the sample value of the by determining the critical region in a two tailed test $(n-k)$ degree of freedom. The $t$-statistics was used to determine the significance of the explanatory variables in the OLS outputs. The parameter was further used to test the hypotheses of the study. F-test was further used to determine the joint significance of the estimates in the equation.

Finally, the economic criteria determine the reliability of the first order test and the standard errors of the estimates. We firstly assumed that there is no autocorrelation or serial correlation of the random variables. To test the validity of the assumption of non-auto correlated disturbances, we compute the Durbin Watson statistics.

\section{Descriptive Statistics}

The following report the mean, median, and standard deviation of the variables of the study

Table 4.1: Descriptive Statistics for RGDP, $\mathbf{M}_{1}, \mathbf{M}_{2}$, INFR, and EXR

\begin{tabular}{lccccc}
\hline & RGDP & $\mathrm{M}_{1}$ & $\mathrm{M}_{2}$ & INFR & EXR \\
Mean & 4.943667 & 24.73533 & 25.89433 & 20.49333 & 76.61592 \\
Median & 5.100000 & 20.22000 & 22.62000 & 12.10000 & 94.07500 \\
Maximum & 11.36000 & 62.24000 & 57.78000 & 76.80000 & 158.6200 \\
Minimum & -0.690000 & -5.230000 & 1.320000 & 0.200000 & 0.999600 \\
Std. Dev. & 3.060835 & 18.51544 & 15.34671 & 20.00498 & 62.04927 \\
Skewness & 0.196472 & 0.406838 & 0.426843 & 1.502732 & 0.010971 \\
Kurtosis & 2.624988 & 2.251950 & 2.275053 & 4.026276 & 1.220870 \\
Jarque-Bera & 0.368799 & 1.527061 & 1.567908 & 12.60757 & 3.957230 \\
Probability & 0.831604 & 0.466018 & 0.456597 & 0.001829 & 0.138261 \\
\hline
\end{tabular}

Source: Author's Computation using E-view 9.1

Note: $\mathrm{RGDP}=$ real gross domestic product, $\mathrm{M} 1=$ narrow money supply, M2 = broad money supply, INFR = inflation rate, $\mathrm{EXR}=$ exchange rate

From the descriptive statistics results, the mean real gross domestic product growth rate over the period of the study is 4.94 , while $\mathrm{M}_{1}$ (narrow money), $\mathrm{M}_{2}$ (broad money), INFR (inflation rate) and EXR (exchange rate) are: 24.73, 25.89, 20.49, and76.61592 respectively. The standard deviation of real gross domestic product growth rate, $\mathrm{M}_{1}, \mathrm{M}_{2}$, inflation rate and exchange rate reveals that the values in the data set are close to the mean. Thus reflects a small amount of variation of the data of the variables. All the variables positively skewed as indicated by the positive skewness coefficients.

\section{Augmented Dickey Fuller (ADF) Unit Root Test}

The ADF unit root test in this study was employed to solidify the numeric values of the variables. This helped us ensure that the regression outputs were not spurious. The results of the unit root test at level and first difference are presented in table 4.2. 
Table 4.2: Unit Root Test for RGDP, $\mathrm{M}_{1}, \mathrm{M}_{2}$, INFR, and EXR

\begin{tabular}{|c|c|c|c|}
\hline Variable & Level & $1^{\text {st }}$ Difference & $\begin{array}{c}\text { Order of } \\
\text { integration }\end{array}$ \\
\cline { 1 - 2 } RGDP & 1.3774 & 1.9889 & $\mathrm{I}(1)$ \\
\cline { 1 - 1 } $\mathrm{M}_{1}$ & -1.5581 & -2.9116 & $1(1)$ \\
\cline { 1 - 1 } $\mathrm{M}_{2}$ & -1.0345 & -2.2293 & $1(1)$ \\
\cline { 1 - 1 } INFR & -0.2942 & -2.6030 & $1(1)$ \\
\cline { 1 - 1 } EXR & -1.9395 & -2.8639 & $1(1)$ \\
\cline { 1 - 1 } Critical Value @ 5\% & $\mathbf{- 1 . 9 5 8 3}$ & $\mathbf{- 1 . 9 5 9 2}$ & \\
\cline { 1 - 1 } & &
\end{tabular}

Source: Author's Computation using E-views

Table 4.2 show the summary of the unit root test of the variables used for the study. The results shows that all the variables used in the model are all integrated at first difference, symbolized by I(1), all at 5 percent significance level.

\section{OLS Results for Models I \& II}

The Ordinary Least Square (OLS) is used in this study to estimate and determine the impact of the explanatory variables on the dependent variables of the study. The results are presented in tables 4.3 and 4.4 respectively.

\section{Table 4.3: Regression Outputs for Model I}

Dependent Variable: RGDP

Method: Least Squares

Sample: 19852016

Included observations: 30

\begin{tabular}{lllll}
\hline \hline Variable & Coefficient & Std. Error & t-Statistic & Prob. \\
\hline \hline C & 5.378644 & 1.485134 & 3.621656 & 0.0013 \\
M1 & 0.158868 & 0.074099 & 2.143991 & 0.0419 \\
M2 $_{2}$ & -0.162466 & 0.082949 & -1.958629 & 0.0614 \\
EXR & 0.023757 & 0.099586 & 2.385576 & 0.1637 \\
INFR & -0.059128 & 0.033224 & -1.779659 & 0.0873 \\
\hline \hline R-squared & 0.509574 & Mean dependent var & 4.943667 \\
Adjusted R-squared & 0.491106 & S.D. dependent var & 3.060835 \\
S.E. of regression & 0.836677 & Akaike info criterion & 5.074155 \\
Sum squared resid & 201.1684 & Schwarz criterion & 5.307688 \\
Log likelihood & -71.11233 & Hannan-Quinn criter. & 5.148864 \\
F-statistic & 5.191085 & Durbin-Watson stat & 1.648027 \\
Prob(F-statistic) & 0.009167 & & \\
\hline \hline
\end{tabular}

Source: Author's Computation using E-view

The results showed that narrow money supply $\left(\mathrm{M}_{1}\right)$ possess a positive and significant impact on RGDP. Broad money supply $\left(\mathrm{M}_{2}\right)$ possesses a negative and insignificant impact on RGDP growth rate. Exchange rate has a linear and insignificant impact on RGDP growth rate; while 
for inflation rate (INFR), the results predict a nonlinear and insignificant impact on RGDP growth rate in Nigeria.

Further results show that the coefficient of determination $\left(R^{2}\right)$ explained approximately $51 \%$ of the variation/changes in the dependent variable (RGDP growth rate). The test of the aggregate significance of the model also unveils that the model is statistically significant because the Fstatistics $(5.191085)$ is greater than the F-prob(0.009167) which is statistically zero. The Durbin Watson statistic of 1.648027 is greater than the $\mathrm{R}^{2}$ output of 0.509574 . This shows the absence of first order autocorrelation. The Akaike info criterion of 5.07 indicates that the model is correctly specified. The standard error of regression reveals that in about two-third of the time the independent variables explained the dependent variable by exactly 84 percent.

\section{Table 4.4: Regression Outputs for Model II}

Dependent Variable: INFR

Method: Least Squares

Sample: 19852016

Included observations: 30

\begin{tabular}{lcccc}
\hline \hline \multicolumn{1}{c}{ Variable } & Coefficient & Std. Error & t-Statistic & Prob. \\
\hline \hline $\mathrm{C}$ & 4.988841 & 0.399780 & 12.47895 & 0.0000 \\
$\mathrm{M}_{1}$ & 0.158364 & 0.056476 & 2.804075 & 0.0187 \\
$\mathrm{M}_{2}$ & 0.106232 & 0.109901 & 0.966615 & 0.1024 \\
$\mathrm{EXR}$ & 0.650081 & 0.140658 & 4.061743 & 0.9520 \\
& & & & \\
\hline \hline R-squared & 0.689006 & Mean dependent var & 6.380007 \\
Adjusted R-squared & 0.681310 & S.D. dependent var & 0.336225 \\
S.E. of regression & 0.045966 & Akaike info criterion & -3.020716 \\
Sum squared resid & 0.021129 & Schwarz criterion & -2.624995 \\
Log likelihood & 35.18644 & Hannam-Quinn criter. & 8.508300 \\
F-statistic & 2.103845 & Durbin-Watson stat & 1.648007 \\
Prob(F-statistic) & 0.009167 & & \\
\hline \hline
\end{tabular}

Source: Author's Computation using E-view

The results showed that narrow money supply $\left(\mathrm{M}_{1}\right)$ has a linear and significant impact on inflation rate (INFR). This means that every 1 percent increase in narrow money supply led to about 0.16 percent increase in the rate of inflation. Similarly, broad money supply $\left(\mathrm{M}_{2}\right)$ also has a positive and statistically insignificant impact on inflation rate. Also, exchange rate has a linear and statistically insignificant impact on inflation in Nigeria.

The results further revealed that 68 percent of the variation/change in the dependent variable, inflation rate was explained by the explanatory variables in the model. The results also predict that the overall model is statistically significant because the F-statistic is greater than the F-prob (i.e. 2.103845 $>0.009167)$. Finally, the Durbin-Watson statistic value of 1.648007 is greater than the $\mathrm{R}^{2}$ value of 0.689006 ; this suggests the absence of first order autocorrelation.

\section{Conclusion}

The paper evaluated the impact of money supply on varied macroeconomic variables in the Nigerian economy from 1985 to 2016. To achieve the objectives of the study, the ex post facto research design and descriptive statistics was used to observe the variables in retrospect. The Augmented Dickey Fuller test was used to solidify the data and the ordinary least square 
technique was employed to determine the magnitude and direction of the variables in the models. The empirical results showed that narrow money supply and exchange rate has a significant impact on economic growth and inflation whereas, this is not the case for broad money supply and the rate of inflation on economic growth in Nigeria. Ceteris Paribus, the results suggest that economic growth and inflation is a function of money supply (narrow money supply) and exchange rate in Nigeria.

\section{Recommendations}

The following recommendations were made;

1. Accelerate efforts should be put in place to better the exchange rate between the naira and other currencies. This will help avoid the imported inflationary pressure on goods and services in the country.

2. Concerted effort should be made to ensure that efforts aimed at ensuring price stability do not stifle aggregate demand and hence economic growth.

3. Measure should be put in place to improve domestic production. This will reduce demand pull inflation and enhance economic growth.

\section{References}

Adeyeye, E.A. \& Fakiyesi, T.O. (1980). Productivity prices and incomes board and antiinflationary policy in the Nigerian Economy under the Military. Proceedings of the 1980 Annual Conference of the Nigeria Economic Society, Ibadan.

Ajayi, S. L. (1974). An econometric case study of the relative importance of monetary and Fiscal policy in Nigeria. Bangladesh Economic Review, 11, (2).

Aminu, U., \& Amono, A. Z. (2012). Effect of inflation on the growth and development of Nigerian economy: empirical analysis. International Journal of Business and Social Science, 3(10): 183-19.

Anoruo, E. M. (2002). Stability of the Nigerian $\mathrm{M}_{2}$ money demand function in the SAP period. Economics Bulletin, 14(3), 179.

Anyanwu, U. N. I., \& Kalu, A. O. U. (2015). The impact of statutory money supply management and commercial bank loans and advances on economic growth: empirical evidence in Nigeria. Arabian Journal of Business and Management Review, 3(5), 232-250.

Baghebo, M., \& Ebibai, T. S. (2014). Monetary policy and economic growth in Nigeria (19802011). Asian Economic and Financial Review, 4(1), 20-32..

Cochrane. J. (1998). A frictionless view of US inflation. NBER Macroeconomics Annual 323-84.

Fatukasi, B. (2004). Determinants of Inflation in Nigeria: An empirical analysis. International Journal of Humanities and Social Science, 1(18).

Femi, O. T. (2014). Inflation and demand for money in emerging economies: Evidences from Nigeria. Journal of Economics and Sustainable Development, 5(18). Retrieved from: www.iiste.org

Gatawa, N. M., Akinola, I, A. 1., \& Olarinde, M. O. (2017). Impact of money supply and inflation on economic growth in Nigeria (1973-2013). Journal of Economics and Finance,8(3), 637. Retrieved from www.iosrjournals.org. 
Ifionu, E. \& Akinpelumi, O. F. (2015). Macroeconomic variables and money supply: Evidence from Nigeria. An International Multidisciplinary Journal, 9(4), 288-307. doi: http://dx.doi.org/10.4314/afrrev.v9i4.22.

Imoughele, L. E. (2014). Empirical investigation of the impact of monetary policy on manufacturing sector performance in Nigeria (1986-2012). International Journal of Education and Research, 2(1), 1-20.

Kenneth, O. O., Yuni, D. N., \& Ihugba, O. A. (2016). Inflation and growth nexus in Nigeria: An investigation into the simultaneous relationship. International Journal of Development and Economic Sustainability, 4(3), 25-32. Retrieved from: www.eajournals.org.

Mai-Lafia, D. I. (1995). An Empirical Study of Monetary Policy Impact in Nigeria (1968-1988). PhD Thesis, University of Jos (December).

Malik, W. S. (2006). Money, output and inflation: Evidence from Pakistan. The Pakistan Development Review, 45(4).

Nwaobi, G. (2002). A vector error correction and non-nested modelling of money demand function in Nigeria. Economics Bulletin, 3, 1-8.

Odama, J. S. (1974). The demand for money in the Nigerian economy, some comments. Nigerian Journal of Economics and Social Studies, 16(1) 178-188.

Ojo, O. (1974). The demand for money in the Nigerian economy, some comments. Nigerian Journal of Economics and Social Studies, 16(1), 149-152.

Olorunfemi, S., \& Adeleke, P. (2013). Money supply and inflation in Nigeria: Implications for national development. Modern Economy, 4, 161-170. Doi: http://dx.doi.org/10.4236/me.2013.43018.

Olusanya, E. O., \& Rasheed, O. (2009). Modelling the dynamics of inflation in Nigeria. In: Adeola, A., Dipo, B. \& Olofin, S. Applied Econometrics and Macro econometrics Modelling in Nigeria.

Omoke, P. C. (2010). Inflation and economic growth in Nigeria. Journal of Sustainable Development, 3(2), 159-166.

Omotor, D, G. (2010). The Nigerian economy and monetary policy: Some Simple Empirics" MPRA Paper No. 22672, 127.

Onoh, J. K. (1990). The state of the Nigerian economy: An overview of the structural adjustment programme in Nigeria: Impact of SFEM on the Nigerian economy. Nigerian Institute of International Affairs

Osakwe, J. O. (1983). Government expenditure, money supply and prices, 1970 - 1980.CBN Economic and Financial Review, 21(2).

Osuala, A. T., Osuala, K. L., \& Onyeike, S. C. (2013). Impact of inflation on economic, growth in Nigeria- A causality test. Jorind, 11(1), 206-216.

Owoye, O., \& Onafowora, O. A. (2007). Structural adjustment and the stability of the Nigerian money demand. International Business and Economic Research Journal, 3(8), 20-30.

Salam, M. A., Salam, S., \& Feridun, M. (2006). Forecasting inflation in developing nations: The Case of Pakistan. International Research Journal of Finance and Economics.3, 138-159. 
Taiwo, M. (2012). Impact of injection and withdrawal of money stock on economic growth in Nigeria. European Journal of Business and Management Sciences, 4(2), 33-42. Retrieved from www.ajol.info/journals/jorind

Teriba, A. O. (1992). Modelling the demand for money in Nigeria: An application on cointegration and error correction techniques (1960-1989). Economics Bulletin of Ghana. Second series, 4 (4), 30-35.

Teriba, O. (1971). Income distribution and national integration. The Nigerian Journal of Economic and Social Studies, 13(1), 77-122.

Teriba, O. (1974). The demand for money in the Nigerian economy: some methodological issues and further evidence. Nigeria Journal of Economic and Social Studies. 16(1),153-164.

Tobin, J. (1956). Nobel lecture: money and finance in the macroeconomic process. Journal of Money, Credit and Banking, 14(2), 171-204.

Tobin, J. (1969). A general equilibrium approach to monetary theory. Journal of Money Credit and banking, 1, 15-29.

Tomori, J. (1972). The demand for money in Nigeria. Nigeria Journal of Economics and Social Studies (NESS), 4 (3).

Usman, O. A., \& Adejare, A. T. (2014). Money supply, foreign exchange regimes and economic growth in Nigeria. Research Journal of Finance and Accounting, 5(8),121-129. Retrieved from:www.iiste.org. 